\title{
THE POSITION OF THE FREIGHT CARRIERS BEFORE THE CIVIL AERONAUTICS BOARD
}

\author{
StePhen AILE**
}

Who should be in the air freight business, and what are the proper rules of the game? These two questions state the central issues in a battle that has been waged before the Civil Aeronautics Board since the spring of 1946 . The contestants on one side have been the certificated passenger air lines, ${ }^{1}$ their trade association, ${ }^{2}$ and their wholly owned cargo ground service subsidiary. ${ }^{3}$ The carriers in this group, for convenience and because the term describes their principal business, ${ }^{4}$ will hereafter be referred to as the "passenger carriers." The contestants on the other side have been a group of new companies, organized after the cessation of hostilities in the last war, who have devoted almost all of their energies to the development of commercial air freight. For convenience, and again because the term describes their principal business, ${ }^{5}$ these carriers will be referred to as the "freight carriers."

The battle before the CAB has been long and bitter, and it is still going on. That it has been long will be apparent from a glance at the proceedings involved. The Air Freight case, ${ }^{b}$ in which the issue of certification of freight carriers was directly posed, alone has required 65 days of hearings, some 30,000 pages of testimony and exhibits, briefs before examiners, a full year's study by the examiners, a lengthy examiner's report, briefs before the Board, oral argument before the Board, a reopened hearing in order to obtain some additional evidence, a second oral argument before the Board, a tentative decision by the Board, exceptions thereto, new briefs, still another argument before the Board, and at long last, a final decision, on August 2, 1949, on applications most of which were filed in the spring of 1946.

Other proceedings have included the Air Freight Rate case, ${ }^{7}$ in which the freight carriers sought and received from the Board a minimum rate order $^{8}$ halting the

-A.B. I933, Princeton University; LL.B. 1936, West Virginia University; member of West Virginia and District of Columbia bars.

${ }^{1}$ Principally American Airlines, Inc., United Air Lines, Inc., Eastern Air Lines, Inc., Transcontinental and Western Air, Inc., Capital Airlines, Inc., Braniff Airways, Inc., and Chicago and Southern Air Lines, Inc.

The Air Transport Association.

a Air Cargo, Inc.

- Even as late as 1948, passenger traffic accounted for 91.6 per cent of the non-mail revenue of the then certificated trunk line carriers, according to Roadcap, Airline Record 1949. Freight revenues reported to the $\mathrm{CAB}$ at slightly over II million dollars accounted for slightly more than 3 per cent of this revenue.

"Most of the applicants in the Air Freight case have been "freight only" carriers. They have never been permitted to carry air express and have not sought the right to carry air mail or passengers. Some of these companies have had outside sources of revenue from overhaul, maintenance, and modification work, or leasing of aircraft.

${ }^{\circ} \mathrm{CAB}$ Docket No. 8ro.

${ }^{7}$ CAB Docket No. 1705.

${ }^{8} \mathrm{CAB}$ Order, Serial No. E-I639, issued June 2, I948. 
passenger carriers' attempts to decide question number one (who should be in the air freight business) by means of a rate war. Since the rate case, we have had four modifying orders ${ }^{9}$ and a lengthy hearing on the subject of whether less-than-minimum backhaul rates may continue to be employed.10 In addition, the freight carriers, for reasons which will be apparent later on, have intervened in mail rate proceedings $^{11}$ in support of their belief that the sound development of air freight requires a firm decision that mail subsidy will not be used to underwrite freight operations of the passenger carriers.

That this fight has been bitter is understandable. The freight carriers, with all the energy and enthusiasm of the pioneer, have been prepared to fight for the privilege of going forward with a business which they feel they have started. The passenger carriers, on the other hand, never distinguished for their hospitality toward newcomers to the aviation field, ${ }^{\mathbf{1 2}}$ have been particularly resentful of the newly arrived freight carriers, described in a recent Board document as among the "have nots" of aviation."

The Civil Aeronautics Act of 1938 , with its subsidy provision, ${ }^{14}$ has meant, so far at least, that any carrier once engaged in commercial air transportation is there for good, and need have no fear of bankruptcy or failure.15 As a result, the passenger carriers have viewed with real alarm the prospective permanent dilution of their claim on the United States Treasury when any new carrier has sought admission to the club. They have viewed with even more alarm the arrival of freight

- These orders have added temporary less-than-minimum backhaul rates for ccrtain commodities.

${ }^{10}$ This investigation, generally referred to as the Directional Rate Investigation, was addressed to the question of whether these temporary backhaul rates should be continued and whether additional ones should be added.

${ }^{21}$ Principally the Big Four Mail Pay case, CAB, Docket No. 2849, the Big Four Financial Intestigation, CAB, Docket No. 3663, and Mail Cost Investigation of All Trunk Lines, CAB, Docket No. 3666.

${ }^{12}$ Examples of their vigorous opposition to other potential entrants into the aviation ficld may be found in the Feeder cases dealing with the certification of small feeder airlines, the Freight Forwarder case in which freight forwarders sought to engage in "indirect" air transportation, and the "Sea-Air" fight, the common name for the controversy over whether or not steamship lines or other surface carriers could own or operate airlines. In fact, even the Railway Express Agency, responsible for almost all of the passenger carriers' pre-r945 property transportation, was told in the course of the Freight Forwarder case that there would be no place for REA in aviation once the passenger carriers had Air Cargo, Inc., in full operation. $\mathrm{CAB}$ citations for these matters are as follows:

Local Feeder and Pick-Up Air Service, $6 \mathrm{CAB}$ x (I944) and subsequent regional cases; the Freight Forwarder case, CAB, Docket No. 68I; American President Lines, Ltd., et al., Petition 7 CAB 799 (1947) and subsequent separate carrier cases. For REA disavowal see Examiner's Report in the Freight Forwarder case (Docket No. 687), pp. 76-77.

${ }^{13}$ See Respondent's Objections to Petition for a Stay, filed August II, I949, by the CAB in the pending case of American Airlines, Inc. v. Civil Aeronautics Board, No. 10374, United States Court of Appeals for the District of Columbia.

14 "In fixing and determining fair and reasonable rates of compensation [for the carriage of mail] ... the Board shall take into consideration ... the need of each such air carrier for compensation for the transportation of mail sufficient ... together with all other revenue . . . to enable such carricr under honest, economical, and efficient management, to maintain and continue the development of air transportation. ..." Sec. $406($ b), Civil Aeronautics Act of 1938, 52 STAT. 998 (1938), 49 U. S. C. $\$ 486$ (b) (1946).

${ }^{25}$ This statement must be qualified to the extent that the Board has taken steps toward the revocation of two feeder line certificates. 
carriers who insist that they can operate without direct government subsidy of any kind, because these carriers, with that threat, in effect throw doubt on the need for continuation of government subsidy for the passenger carriers at all.

Issue number one, "Who should be in the air freight business," has been decided, at least in so far as the administrative process is concerned. The case was called the Air Freight case, Docket 8Io et al. That case was a proceeding to review and rule upon applications filed by thirteen freight carriers for certificates of convenience and necessity. In that proceeding (aside from questions of fitness and ability of individual carriers which are beyond the scope of this paper) the position of the freight carriers may be stated as follows:

(I) The public interest requires that air freight service expand and grow until it becomes a major component of the nation's air transportation system.

(2) It is in the public interest that such an air freight service be developed efficiently, soundly, and rapidly.

(3) Freight carriers carrying nothing but freight will aid substantially in this development.

(4) The presence of freight carriers will work no injury on previously certificated passenger carriers; much less will any such injury offset the benefit to be gained.

The first two propositions have not been the subject of great debate. Most every observer realizes that the large fleet of all-cargo aircraft, immediately convertible to wartime use, ${ }^{10}$ which a fully developed air freight system would require, would be a tremendous asset to the nation in the event of war. Furthermore, almost everyone agrees that a fully developed air freight industry would be a substantial aid to the functioning of the nation's economy and the lowering of costs and increasing of speed of distribution in time of peace. ${ }^{17}$

The argument has centered around the third and fourth of the propositions stated above. As to the third, it has been the position of the freight carriers that single-purpose companies, who must look to air freight and air freight profits as their principal source of income, will have an incentive to go forward with the business, to search for new traffic, and to seek new methods of improving efficiency, which a multi-purpose carrier would not have. This, incidentally, is a theory which

\footnotetext{
${ }^{16}$ A passenger plane with its plush interior and fixed seating arrangement must be altered substantially before it is of value for military transport use. Not only must the seats and plush lining be removed, but the floor must be strengthened and a tie down arrangement installed. When this is done, the passenger plane is only as ready for military use as is the freight plane in the first instance. If real cooperation on plane requirements between the air force and companies engaged in air freight service can be achieved, then the air freight fleet can be a military air transport fleet in being in the event of war.

${ }^{17}$ See the statement of the Secretary of Commerce before the President's Air Policy Commission on November 26 , 1947, speaking by analogy of the effects of the improved railroad service after World War I, "The most important factor, however, was the reduction in inventories which was made possible by the improved services, in addition to the capital savings ultimately resulting in lower prices; the reduced need for large and relatively idle inventories increases the stability of our economy."
} 
has the whole-hearted support of the passenger carriers when they attempt to fight off the threatened invasion of the aviation field by steamship lines and railroad companies. ${ }^{19}$

Furthermore, the freight carriers contend that since they have not sought government subsidy, and will not receive it, but must be dependent on freight revenues and profits if they are to be successful, it follows that they have an incentive to keep costs down which no other air carrier has, or could have, and the lowering of costs for air freight is an absolute sine qua non to the development of the business, since low rates depend on low costs, and without low rates no major increases in volume can be achieved.

In support of these propositions, the freight carriers point to the record of what has happened in air freight so far, and the part which they have played in it. Prior to 1945 the volume of air freight which had been carried was so small that it was not even reported separately to the Civil Aeronautics Board. In I945 the total amount of air freight reported was $1,227,527$ ton-miles. ${ }^{20}$ The smallness of this figure can be understood when it is realized that one plane with a capacity of but I0,000 pounds hauls 12,200 ton-miles of air freight on one trip from New York to Los Angeles. As of January I, I946, only American Airlines and TWA had freight tariffs on file. American's tariff had been filed in October, I944, and listed rates averaging around 35 cents a ton-mile and going as high as $5^{\circ}$ cents, rates which negative any desire or intent to engage in a volume air freight business.

Early in 1946 the picture changed markedly. A substantial group of new companies was formed, largely by young men anxious to apply the material hauling and handling techniques and methods developed by the Air Transport Command and the Naval Air Transport Service to commercial transportation. All of these companies were long on enthusiasm, and some were adequately financed. The founders of these companies were convinced that air freight costs could be reduced low enough to permit rates which in turn would attract air freight business in volume. American Airlines' figure of 35 cents was demonstrably much too high.

Slick Airways started in business in March of 1946 with rates at 18 cents a tonmile, and was shortly enabled to reduce them to 14 cents as costs per ton-mile declined with volume. With the establishment of these rates commercial air freight was born.

By the end of 1946, ten freight carrier applicants in the Air Freight case, operating at the time as contract carriers, had hauled an estimated 27,000,000 ton-miles

\footnotetext{
${ }^{10}$ In that controversy, the fact that they are engaged in air transportation alone is urged as the reason why they are better able to go forward with the business than any surface carrier would be. "Air transportation is not an adjunct to anything; it is a new business selling a new product and the responsibility for the solution of its problems must be given to those whose sole interest lies in developing it. The United States air transportation cannot reach its full potentiality in the hands of those who regard it as a part-time job." (Statement of Robert Ramspeck, Executive Vice-President, Air Transport Association, hearings on bills relative to overseas air transportation, pp. 1018-19.) The freight carricrs say that the same thing is true about air freight.

${ }^{20}$ Reports to $\mathrm{CAB}$.
} 
of freight. Of this total, Slick Airways had hauled $I I, I 98,322^{21}$ ton-miles, or over nine times the total passenger carrier haul reported for the preceding year, 1945. This demonstration of the possibilities inherent in the transportation of freight by air did not go unnoticed by the passenger carriers. In 1946, twelve passenger carriers carried $13,969,227$ ton-miles of air freight in domestic operations. ${ }^{22}$ No one seriously contends that the passenger carriers would have hauled more than this amount had no new freight carriers come into the field. Actually, most observers agree with an expert from the Department of Agriculture, who testified in the Air Freight case as follows: ${ }^{23}$

It is my opinion that these carriers (the freight carriers) have had a profound effect on the development of air freight. I am convinced that, if these specialized air freight carriers had not been in existence during the past year or more, the reduction in air freight rates which has occurred would have been much less, the volume of air freight handled would have been of minor proportions, and we would not have explored air cargo potentials to nearly the extent which has been done.

The year 1947 saw a continuation of the phenomenal growth of air freight. Freight carriers carried $45,299,885$ ton-miles of air freight, and sixteen passenger carriers carried $38,870,698$ ton-miles. ${ }^{24}$ This total of nearly $84,000,000$ represents a phenomenal increase over the $1,000,000$ figure of two years before. Slick Airways again was in the van with a total of $21,937,083$ ton-miles. ${ }^{25}$

The year 1948 saw the freight industry grow to the imposing figure of $116,000,000$ ton-miles. Of this total, the passenger carriers carried some $70,000,000$, and the freight carriers carried approximately $46,000,000 .^{26}$ The decline in the share of the freight carriers is accounted for largely by a reduction in the number of companies still participating in the business. ${ }^{27}$ The regulatory process had taken a long time and a sharp application of economic sanctions by the passenger carriers had taken its toll. The leader in the field, however, still was Slick Airways with 26,581,718 ton-miles hauled in 1948 as against 21,818, I33 ton-miles for American Airlines. ${ }^{28}$

The freight carriers also contend that the fourth proposition-namely, that the certification of freight carriers would work no substantial injury to the passenger carriers-is largely answered by this record in air freight. The record demonstrates that the freight carriers' presence in the business has actually increased the amount of freight which the passenger carriers have carried and, further, that those passenger carriers who have had the most competition from freight carriers have carried the most freight. Besides, the freight carriers contend, even if the passenger carriers were to lose freight business to the freight carriers, it is not clear that such losses

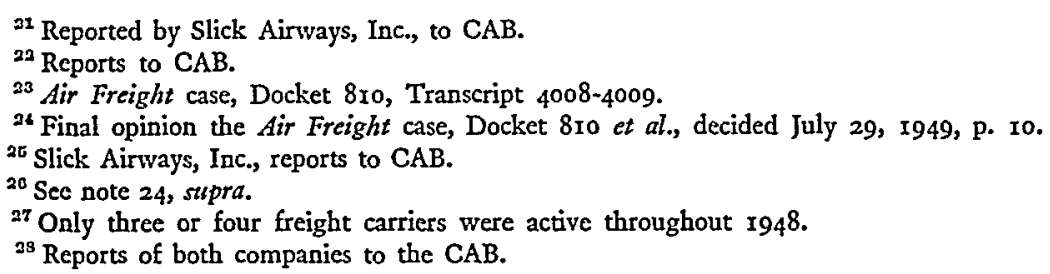


would cause financial injury. As is pointed out hereafter, it is doubtful that the freight business can be so coordinated with the passenger business, as presently operated, as to make the freight business profitable to the passenger carriers.

On August 2, 1948, certificates of convenience and necessity for transcontinental routes were awarded to two air lines, Slick Airways, Inc. ${ }^{29}$ and the Flying Tiger Line, $^{30}$ and a north-south certificate, covering a route from Florida and Louisiana to New York and the midwest, was awarded to United States Airlines. ${ }^{31}$ In addition, Airnews received a certificate calling for local operations in southern Texas. ${ }^{32}$ In the course of the opinion accompanying this decision the Board found: $:^{33}$

The certification of unsubsidized all-cargo carriers requires such carriers to bend their efforts and to direct their abilities and skill to the full development of the air freight potential. Such carriers will not be able to rely on passenger operations or mail payments to furnish the greater portion of their revenues. They will live and prosper only

${ }^{20}$ Slick Airways, Inc., authorized to engage in air transportation with respect to property, for a period of five years, between any point or points in any of the following groups of points and any point or points in any other of said groups: the terminal point Los Angeles, the intermediate points, Bakersficld, Brawley-El Centro, Fresno, Long Beach, Oakland, Sacramento, Salinas-Monterey, San Diego, San Francisco, Santa Barbara, Stockton, and Thermal; the intermediate point Phoenix; the intermediate points Brownsville, Corpus Christi, Eagle Pass, Fort Worth-Dallas, Houston, Laredo, Mission, and San Antonio; the intermediate point Kansas City; the intermediate points Akron, Chicago, Cincinnati, Cleveland, Columbus, Dayton, Detroit, Fort Wayne, Indianapolis, Louisville, Peoria, St. Louis, South Bend, and Toledo; the intermediate points Allentown, Baltimore, Boston, Harrisburg, Hartford, New York, Newark, Philadelphia, Pittsburgh, Providence, Washington, Richmond, and Wilmington; the intermediate point Rockland; and the terminal point Portland.

${ }^{30}$ The Flying Tiger Line, Inc., authorized to engage in air transportation with respect to property, for a period of five years, between any point or points in any of the following groups of points and any point or points in any other of said groups: the terminal point Los Angeles, the intermediate points Bakersfield, Brawley-El Centro, Fresno, Long Beach, Oakland, Sacramento, Salinas-Monterey, San Diego, San Francisco, Santa Barbara, Stockton, and Thermal; the intermediate points Longview, Portland, Seattle, Wenatchee, and Yakima; the intermediate point Minneapolis-St. Paul; the intermediate point Denver; the intermediate points Des Moines and Omaha; the intermediate points Akron, Chicago, Cleveland, Detroit, Fort Wayne, Grand Rapids, Milwaukee, South Bend, and Toledo; the intermediate points Albany, Binghamton, Boston, Buffalo, Hartford, New York, Newark, Philadelphia, Providence, and Rochester; the intermediate point Rockland; and the terminal point Portland.

${ }^{31}$ U. S. Airlines, Inc., authorized to engage in air transportation with respect to property, for a period of five years, $(I$ ) between any point or points in any of the following groups of points and any point or points in any other of said groups: the terminal point Miami, intermediate points Atlanta, Belle Glade, Fort Myers, Jacksonville, Lakeland, Ocala, Orlando, Sarasota-Bradenton, Birmingham, Savannah, Tampa-St. Petersburg, Valdosta, and West Palm Beach; the intermediate points Baton Rougc, Gulfport-Biloxi, Hammond, Mobile, Morgan City, and New Orleans; the intermediate points Akron, Chicago, Cincinnati, Cleveland, Columbus, Dayton, Detroit, Grand Rapids, Indianapolis, Louisville, Milwaukee, South Bend, and Toledo; and the terminal point Minneapolis-St. Paul; and (2) between any point or points in any of the following groups of points and any point or points in any other of said groups: the terminal point Miami, intermediate points Atlanta, Belle Glade, Fort Mycrs, Jacksonville, Lakeland, Ocala, Orlando, Sarasota-Bradenton, Birmingham, Savannah, Tampa-St. Petersburg, Valdosta, and West Palm Beach; the intermediate points Baton Rouge, Gulfport-Biloxi, Hammond, Mobile, Morgan City and New Orleans; the intermediate points Albany, Allentown, Baltimorc, Binghamton, Boston, Buffalo, Harrisburg, Hartford, Newark, Philadelphia, Pittsburgh, Providence, Rochester, Washington, Richmond, and Wilmington; and the terminal point New York.

${ }^{32}$ Airnews, Inc, authorized to engage in air transportation with respect to property, for a period of five years, between the terminal point San Antonio, the intermediate point Becville, and the tcrminal point Corpus Christi; and between the terminal point San Antonio, the intermediate points McAllen and Harlingen, and the terminal point Brownsville, subject to condition.

${ }^{33}$ Final opinion the Air Freight case, Docket No. 8ro, decided July 29, 1949, pp. 30-3r. 
through their ability to develop an economic business and by constant search for new techniques, new business, and new equipment. To the extent that they succeed in such endeavors, they will, by their example, benefit the presently certificated carriers and air transportation as a whole.

The decision in the Air Freight case brings to a conclusion the administrative phase of the process by which the question, "Who should be in the air freight business," is to be determined. The passenger carriers, however, have not been content to rely on the judgment of the Civil Aeronautics Board, and subsequent reviewing courts, in their effort to obtain a decision which reserves the field solely to them. They have undertaken by competitive means to drive all prospective applicants from the air freight field, and these efforts have met with an unfortunate degree of success. $^{34}$ It is this last campaign which has given rise to the second issue, "What are proper rules of the game," an issue which is still before the Board and before Congress as well.

To see the competitive picture in its true light, one must remember that the passenger carriers have not ordinarily been advocates of a low-rate-high-volume approach to air transportation. For instance, passenger rates per ton-mile have stayed in the neighborhood of 55 cents to 60 cents for some time and, with the exception of Capital Airlines, the passenger carriers are still either opposed ${ }^{35}$ or were somewhat reluctant and recent converts to the low rate coach service type of business, ${ }^{36}$ where rates are in the neighborhood of 40 cents a ton-mile. The public pays an average rate of $6 \mathrm{r}$ cents a ton-mile for air express, and the Railway Express Agency has been completely unsuccessful in its efforts over the last several years to obtain the passenger carriers' consent which, under the contract, is a prerequisite to a rate reduction. ${ }^{37}$ The so-called "service" rate for the carriage of mail for the major passenger airlines which are not in the "need" class" runs in the neighborhood of 60 cents a ton-mile. ${ }^{39}$ Air parcel post rates under an act sponsored by the passenger carriers are paid 60 cents and up a ton-mile for carrying it. ${ }^{40}$

s' The gory details may be found in the dissenting opinion of Member Jones in the Air Freight case, Docket No. 810, et al. Member Jones does not discuss the part the passenger carriers played in bringing about these losses.

${ }^{36}$ Some, such as United Air Lines, Inc., as of October, 1949, still did not believe in the coach business.

${ }^{86}$ Eastern Air Lines, Inc., instituted its first coach service at the end of September, 1949. American announced in late October that a 45 cents a ton-mile service would be instituted in January, 1950.

${ }^{37}$ Transcript of testimony, Air Freight Rate case, Docket No. 1705 et al., pp. 2645-7.

${ }^{88}$ Carriers in the "need" class included those carriers whose mail pay is in excess of the amount necessary to pay the costs of the mail service, plus a reasonable return to the carrier. A "service" rate as distinguished from a "need" rate would presumably be a rate which includes no element of subsidy. That this is not the case, however, is apparent from the opinions of the Board establishing the present "service" rate. Dockets Nos. 3309, 302I, 32II, 2849, 3014, March 29, I948.

${ }^{30}$ Dockets Nos. 3309, 302x, 3211, 2849, 3014. Mail rates for these carriers are set on a sliding scale depending on volume. The range is from 45 cents a ton-mile to 75 cents, but has averaged, according to $\mathrm{CAB}$ records, in the neighborhood of 60 cents.

${ }^{60}$ Apparently no data are available indicating the average ton-mile rate paid by the public for air parcel post; however, the carriers are paid for the carriage of parcel post as if for letter mail. Accordingly, air parcel post rates to the public should be in excess of 60 cents a ton-mile, unless the post office is to suffer substantial losses in this business. The freight carriers urge that legislation be passed 
The founders of the new postwar freight lines, on the other hand, were convinced that rate policies such as these would effectively block the development of any appreciable volume of commercial air freight. The rates in American's 1944 tariff had reflected such a policy and had resulted in the generation of no appreciable freight traffic. Accordingly, convinced that economical operations would justify low rates, the new carriers went into business in early 1946 at rates in the neighborhood of 18 cents, and soon thereafter reduced them to I4 cents as costs dropped with increasing volume. These carriers were at that time operating as contract carriers, since the authority to engage in common carrier operations was not effective until August I, I947, ${ }^{42}$ and accordingly filed no tariffs.

The first inkling of what was to be expected from the passenger carriers in the rate field came in the middle of June, 1946, when American Airlines announced the organization of its Contract Air Cargo Division. ${ }^{43}$ There was considerable publicity about the rates that this division would charge ${ }^{44}$ and, apparently in keeping with American's purpose, the rate level in air freight was immediately and severely depressed. For instance, for Slick Airways the average rate on the freight business dropped to 0.4 cents a ton-mile, although representatives of that company have always insisted that they never once undercut one of American's offerings of service. ${ }^{45} \mathrm{CACD}$ was not long in the field, but the process of convincing shippers that freight rates had to be higher than those announced by American was difficult. ${ }^{40}$

Contract rate levels had been worked back up to between $121 / 2$ cents and 13 cents a ton-mile by July of 1947. With the approach of August I, I947, the effective date of permission to engage in common carrier operations, Slick Airways filed its first common carrier tariff, containing rates averaging around 12.75 cents per ton-mile, rates slightly above the level to which its contract rates had been raised by that time, and rates at which Slick Airways could operate at a profit as September and October operations that year proved. Similar tariffs were filed by most of the freight carriers who planned to operate under the Noncertificated Cargo Carriers Exemption Order, Section 292.5, of the Economic Regulations of the Board.

under which carriers would be paid for carrying parcel post at ratcs prevailing for air freight. This could have meant air parcel post available to the public at something like 25 cents a ton-milc, and a profit to the post office.

"Section 292.5 of the Economic Regulations of the CAB. Under a recent recodification this section is now known as Part 295.

13 American Airlines, Inc, took the position that it could cngage in transcontinental off-routc air freight operation with a large maintenance base at St. Joseph, Missouri, apparently on the theory that these operations were authorized under Section $40 \mathrm{I}(\mathrm{f})$ of the Civil Aeronautics Act. "Any air carrier may make charter trips or perform any other special service, without regard to the points named in its certificates under regulations prescribed by its authority." 52 STat. 987 (1938), 49 U. S. C. $\$ 48 \mathrm{I}(\mathrm{f})(1946)$.

"See American Aviation Daily, June 6, 1946, describing CACD publicity: "Tariffs will be based on volume and frequency and the rate structure is said to be not only the lowest ever promulgated by any airline, but is generally under the lowest rates quoted by non-scheduled carriers."

${ }^{45}$ See Slick Airways, Inc.'s Brief to the Board in the Air Freight Rate case, p. 7.

"American Airlines, Inc.'s publicity about II cents a ton-mile rate made the job of selling 12 cent and $12 \frac{1}{2}$ cent rates extremely difficult. 
As of August $x$, the passenger carriers put into effect a consolidated tariff known as the Johnson tariff with rates averaging in the neighborhood of 26 cents a tonmile, and going down as low as 14 cents (only for shipments of 16,000 pounds and above). Shortly more than a month later, however, American, PCA, TWA, and United filed tariffs to become effective October 5, 1947, for a list of specific commodities, accounting for the bulk of air freight business at that time. These rates in the new tariffs applied only to points served by the freight carriers and operated to undercut the existing tariffs of the freight carriers on approximately one-half of the business. ${ }^{47}$ Petitions to suspend these tariffs were promptly filed by the freight carriers and promptly denied by the Board. ${ }^{48}$ This last step resulted in further cuts and reductions by American, PCA, and TWA, to become effective late in October. Petitions to suspend were again filed and were on this occasion granted and the whole matter of rates in air freight was set down for hearing. ${ }^{49}$

The freight carriers insisted that the passenger carriers, in spite of substantially higher costs of operation, were attempting to drive the freight carriers out of the business by means of a rate war, and they pointed out that even their own tariffs, filed on August $\mathrm{I}$, had become too low as the result of sharp increases in the price of gasoline, and some raises in wages in line with the general trend at that time. ${ }^{50}$ The passenger carriers, on the other hand, begged for freedom of action with respect to rates, contending that the industry was still in the development phase and that the rigidity which any form of rate regulation would impose would seriously hamper development. ${ }^{51}$ They also contended that cut rates could be justified on the basis of their costs, such costs being computed for this purpose on what the Board later called the "no cost theory" or on the "additive" or "out-of-pocket cost concept." The essence of each of these theories was that the air freight service should be made to bear only that portion of the airlines' costs which could have been avoided had no freight been carried. ${ }^{53}$ The Board rejected the contentions of the passenger carriers and issued a rate order forbidding rate reductions below i6 cents a ton-mile for the first 1,000 ton-miles, and $x_{3}$ cents a ton-mile thereafter. ${ }^{54}$

For the most part, this action effectively brought the rate war to an end. Except for the fact that the order has served to retard the development of certain perishable and other items needed to correct the traditional directional unbalance in traffic by strengthening the backhaul from California to New York and from Texas to New York, the order has been extremely salutary. It need not have had even this retard-

\footnotetext{
${ }^{47}$ For a discussion of these and the later rate cuts, see the opinion of the Board in the Air Freight Rate case, Docket No. 1705, et al., decided April 21, 1948, pp. 234 and 235.

${ }^{18} \mathrm{CAB}$ Order, Serial No. E-852 and E-853.

${ }^{\circ} \mathrm{CAB}$ Order, Serial No. E-9r6.

80 These increases amounted to over $\$ 20,000$ a month for Slick Airways, Inc., alone.

EI Sec briefs filed on behalf of the principal passenger carriers in this proceeding.

${ }^{63}$ See the Board's opinion in the Air Freight Rate case, Docket No. I705 et al., pp. 8 and 9.

63 These theories produce some remarkable results. For instance, unit costs increase with volume, since volume requires additional freight handlers, and, sooner or later, all-cargo planes, which must be charged, in part at least, to the freight business.

54 CAB Order, Serial No. E-1639.
} 
ing effect, but for the passenger carriers, who, mirabile dictu, after resisting with all their energy the establishment of minimum rates for the west and southbound haul for commodities for which there is considerable competition, have reversed their position and become disciples of rigidity in rate regulation in so far as less-thanminimum rates for commodities not now moving by air are concerned."

This history of the activities of the passenger carriers in the rate field demonstrates that the ousting of the freight carriers is the prime objective. Therefore, it is only natural that other than rate methods of competition have been used as part of this effort. Extravagant offerings of service, illustrated by the unbelievably low load factors of the passenger air lines' all-cargo flights, ${ }^{56}$ expensive advertising and propaganda campaigns, ${ }^{57}$ have been used and represent, in the opinion of the freight carriers, improper forms of competition for air freight, particularly if these offerings of service and advertising and propaganda campaigns are financed not out of receipts from air freight, but rather by mail subsidy or, perhaps, by revenues from a suddenly profitable passenger business.

The passenger airlines have resisted every effort to determine what the air freight service actually costs them. American Airlines went through the whole Air Freight Rate case in apparent complete ignorance of what its costs per ton-mile were for

\footnotetext{
${ }^{55}$ Compare the following statements: The first from American Airlines, Inc.'s brief to the Bonrd in the Air Freight Rate case, when American was arguing against any rate regulation:

"What the future holds in the way of rate adjustments that may be essential to full utilization of cargo equipment cannot be foretold at this time. An indication of the type of adjustment that may prove useful lies in the historical unbalance of traffic movement. The produce grown in California and Texas may be a partial solution that would bring about a better balanced freight operation, but such traffic may move only at a lower rate than is necessary to create westbound and southbound volume. Anyone concerned with the continued development of freight recognizes this, but the noncertificated carriers ask you to embark upon a minimum rate regulatory program which must inevitably interfere with such developments."
}

The second from American's brief in the Directional Rate case, where American is opposing any lessthan-minimum rates designed to produce new traffic:

"The justification for these departures from the established minimums is that the volume of traffic moving in those directions is substantially less than the movement in the opposite direction. American Airlines urges the Board to disapprove the rates requested because they are unrclated to the present or attainable costs of providing freight service and because they will prevent the sound and economic development of the freight rate business."

${ }^{56}$ See American Airlines, Inc.'s Exhibits in the Air Freight case, Docket No. 8to, et al., dated November, 1948, Parts E and I.

"See American Aviation Daily of July 6, I948:

"A two-page advertisement appearing in the July 3 issue of Editor and Publisher, over the signatures of 'The Established Airlines of the United States,' calls attention to the job the certificated airlines have done in developing air cargo since the war and outlining their arguments against certification of the all-cargo airlines seeking to enter the field in competition with them. Petition of the freight lines is termed 'a threat to the air transportation rights of all the 400 towns and cities now served, and to the economic stability of the airline systems serving the United States.' The ad also appeared in 'Broadcasting' and in 'Publishers' Auxiliary:' "

See also American Aviation Daily, July 16, I948:

"The Air Transport Association currently is distributing through its Public Relations Advisory Committee and member airlines 75,000 copies of a pamphlet titled 'Fact and Fiction Regarding the Nation's Airlines,' in which it presents the case of the 'established airlines' (i.e., the certificated lines) in their fight to block certification of all-cargo carrier applicants in the Air Freight Case." 
carrying freight. 5 The Civil Aeronautics Board has from time to time indicated that accurate and usable information on this subject was imperative if proper regulation in this field was to be had, stating, in the opinion in the Air Freight Rate case in April, $1948: 59$

In this connection it is apparent from the record that the development of more reliable cost data will become increasingly necessary if the air freight service expands.

During the past year lengthy hearings were held before the so-called Johnson Committee in the United States Senate on legislation designed to sever subsidy from mail pay. ${ }^{00}$ Any such severance would, as a corollary measure, require the separate costing of the freight service. Desirable as such legislation is, it is the position of the freight carriers that no new legislation is required to achieve this end, but that the Civil Aeronautics Board could and should establish a method of allocation for determining the cost of this service. Of course, any method of allocation is subject to criticism, and the passenger carriers to date have limited their contribution to the problem by pointing out the fallacies in whatever method is suggested without ever coming forward with one which they recommend. The freight carriers feel that the Board should select a method, to be changed or improved when the passenger carriers come forward with a better one.

The importance of this problem cannot be overstated. It has been contended, for instance, that in 1948 the passenger carriers lost $\$ 12,000,000$ carrying air freight on which the revenue was considerably less than that figure. ${ }^{61}$ Of course, this may or may not be true, depending upon the validity of the allocations of joint $\operatorname{cost}^{62}$ which are used. While it is perfectly true that any calculation of air freight costs of the passenger carriers depends on a series of arbitrary assumptions and is subject to criticism on some score or other, it is equally true that if one of the freight carriers, such as Slick Airways, were to operate with the load factors which the passenger airlines have experienced and were to add to its operating costs the costs of the advertising and the contributions to ATA and Air Cargo, Inc., the freight airline would soon be in bankruptcy. ${ }^{63}$

The metaphysics and the ethics of this situation can be debated at length. No one will come up with a formula for determining to the satisfaction of everybody and for all purposes just what air freight costs the passenger carriers per ton-mile. Nevertheless, from the point of view of the freight carriers, it is imperative that the Civil Aeronautics Board announce that freight losses will not be made up out of

\footnotetext{
68 American has since indicated by statement of counsel in the course of the last oral argument of the Air Freight case that current rates barely cover direct operating costs. Air Freight case, oral argument, June 13, 1949, Vol. I, p. Io.

${ }^{60}$ See opinion Air Freight Rate case, Docket No. I705, et al., decided April 21, 1948, p. ro.

60 The Senate Committee on Interstate and Foreign Commerce.

${ }^{21}$ I6 J. AIR L. AND CoM. 253, 268 (1949).

02 Joint costs are taken to include all costs not directly attributable to a specific service, such as the president's salary, office rent, flying costs, etc.

${ }^{3}$ See Slick Airways, Inc.'s Exhibit SA-3, p. SA-5 in the Air Freight Rate case, Docket No. I705 et al., dated January 28, 1949 .
} 
mail pay and that the Board select a formula for determining freight costs for the purpose of enforcing this rule. The freight carriers recognize that some of the passenger carriers have contended that their freight operations, although operated at a loss, if the costs thereof are determined on an allocated basis, have none the less served to reduce the mail pay needs of these carriers because a substantial portion of these costs have to be incurred anyway. Arguments and calculations of this latter sort cease to have validity as the air freight operations of the passenger carriers expand, and particularly as the passenger carriers begin to employ all-cargo flights for the purpose of handling air freight. In addition, a proper formula for allocating costs will reflect the much higher cost of the all-cargo service and will give the passenger carrier the benefit of lesser costs on the freight hauled in passenger planes and on passenger schedules. As a matter of regulatory policy, dictated by the public interest in the future development of the air freight industry, and required by simple fairness, the Board must take, at an eariy date, some such step to see to it that the United States Treasury ceases to underwrite one side in the air freight battle. The Board should further require that the passenger carriers, in their published financial data, disclose the relationship between freight revenues and freight costs determined on the basis of the allocation described above.

Possibly it is too much to ask that the passenger carriers be prevented from using their own capital or revenues from the passenger and express business to pay the costs of competing for air freight. Certainly, however, the freight carriers have a right to ask that the United States Treasury not be used to subsidize the fight against them and, further, that to the extent that capital and other revenues of the passenger carriers are used to support the competitive effort, the stockholders, the Board, and the general public be so informed.

If such action had been taken long ago, we would not have witnessed the rate wars and other destructive battles for the air freight business which have gone on. The passenger carriers would not have been permitted to fight the Air Freight case on the basis that the losses which they had incurred and the losses which they had imposed on the freight carriers were a reason why no new carriers should be certificated..$^{64}$

If the second question, "What are proper rules of the game," can be answered by such action, then there is every reason to believe that the four newly certificated freight carriers will grow and prosper, and that with their growth the air freight industry will enjoy a rapid and efficient advance toward the one billion ton-mile potential which has been predicted for it.

\footnotetext{
a This argument was made with considerable force and no little effect. See, for instance, the dissenting opinion of Member Jones, who relies heavily on freight carrier losses as a reason why they should not be certificated.
} 